\title{
CALIBRATION OF A WEIGHING LYSIMETER FOR MEASURING COCOA EVAPOTRANSPIRATION ${ }^{1}$
}

\author{
GERLANGE SOARES DA SILVA ${ }^{2 *}$, FRANCISCO ADRIANO DE CARVALHO PEREIRA ${ }^{2}$, RODRIGO ALMEIDA \\ SANTANA $^{3}$, THAÍS NASCIMENTO MENESES ${ }^{2}$, OSWALDO PALMA LOPES SOBRINHO ${ }^{4}$, ALEX SANTANA DO \\ ROSARIO ${ }^{3}$
}

\begin{abstract}
Well-operated and calibrated weighing lysimeters reliably determine the water demand of agricultural crops, and the quality of the data is evaluated through the error analyses attributed to the instrument. The objective of this study was to determine performance parameters of a weighing lysimeter and to evaluate its adequacy for the direct determination of cocoa crop evapotranspiration. The lysimeter with 1.44 $\mathrm{m}^{2}$ surface, supported on four load cells installed in the experimental area of the Graduate Program in Agricultural Engineering of the Universidade Federal do Recôncavo da Bahia, was calibrated at 3:00 a.m., using known masses at intervals of 02 minutes in five cycles of addition and removal. Data were collected using a datalogger coupled to four load cells with an individual capacity of $1000 \mathrm{~kg}$, programmed to perform readings every 01 second, storing the averages of 15 minutes. The lysimeter showed excellent accuracy, with $\mathrm{r}^{2}$ greater than 0.99 in the correlation between the standard masses and the signal of the load cells and standard error of linear regression estimate of $0.03 \mathrm{~mm}$. The combination of repeatability and hysteresis errors with an uncertainty of $0.19 \%$ showed that the load cells have accuracy of $\pm 0.07 \mathrm{~mm}$, with resolution of $0.00033 \mathrm{mV}$, and sensitivity to detect mass changes below $0.1 \mathrm{~mm}$, the system is adequate for direct measurement of cocoa ETc at time intervals of less than one hour.
\end{abstract}

Keywords: Theobroma cacao L. Agricultural instrumentation. Crop water demand.

\section{CALIBRAÇÃO DE UM LISÍMETRO DE PESAGEM PARA MEDIÇÃo DA EVAPOTRANSPIRAÇÃO DE CACAUEIRO}

\begin{abstract}
RESUMO - Lisímetros de pesagem bem operados e calibrados determinam com confiabilidade a demanda hídrica de culturas agrícola, sendo a qualidade dos dados, avaliada através das análises de erros atribuídos ao instrumento. Objetivou-se com o presente estudo, determinar parâmetros de desempenho de um lisímetro de pesagem e avaliar a sua adequação à determinação direta da evapotranspiração da cultura do cacaueiro. $\mathrm{O}$ lisímetro de $1,44 \mathrm{~m}^{2}$ de superfície, apoiado sobre quatro células de carga instalado na área experimental do Programa de Pós-Graduação em Engenharia Agrícola da Universidade Federal do Recôncavo da Bahia, foi calibrado as 3:00 horas da manhã, utilizando massas conhecidas em intervalos de 02 minutos em cinco ciclos de incrementos e retiradas. Os dados foram coletados utilizando um datalogger acoplado a quatro células de carga com capacidade individual de $1000 \mathrm{~kg}$, programado para efetuar leituras a cada 01 segundo, com armazenamento das médias de 15 minutos. O lisímetro apresentou excelente precisão com $\mathrm{r}^{2}$ superior a 0,99 de correlação entre as massas padrão e o sinal das células de carga e erro padrão de estimativa da regressão linear de $0,03 \mathrm{~mm}$. A combinação dos erros de repetitividade e histerese com uma incerteza de $0,19 \%$ mostrou que as células de carga tem acurácia de $\pm 0,07 \mathrm{~mm}$ e com resolução de $0,00033 \mathrm{mV}$ e sensibilidade para detectar mudanças de massa inferior $0,1 \mathrm{~mm}$, o sistema é adequado para medição direta da ETc do cacau em intervalos de tempo inferiores a uma hora.
\end{abstract}

Palavras chave: Theobroma cacao L. Instrumentação agrícola. Demanda hídrica de culturas.

\footnotetext{
${ }^{*}$ Corresponding author

${ }^{1}$ Received for publication in $01 / 03 / 2020$; accepted in 05/20/2020.

${ }^{2}$ Postgraduate Program in Agricultural Engineering, Universidade Federal do Recôncavo da Bahia, Cruz das Almas, BA, Brazil; gerlangesoares@hotmail.com - ORCID: 0000-0002-0254-2159, fadriano64@gmail.com - ORCID: 0000-0002-3528-3261, th41s.nascimento@gmail.com - ORCID: 0000-0001-7337-0115.

${ }^{3}$ Center for Agrarian, Environmental and Biological Sciences, Universidade Federal do Recôncavo da Bahia, Cruz das Almas, BA, Brazil; rodrigoufrb@hotmail.com - ORCID: 0000-0002-2293-5996, alexsantana02@hotmail.com - ORCID: 0000-0003-4343-934X.

${ }^{4}$ Postgraduate Program in Agrarian Sciences, Instituto Federal de Educação, Ciência e Tecnologia Goiano, Rio Verde, GO, Brazil; oswaldo -palma@hotmail.com - ORCID: 0000-0002-4632-695X.
} 


\section{INTRODUCTION}

The yield of agricultural crops depends on the water factor that regulates their physiological and metabolic activities (LIMA et al., 2014). Considering the temporal and spatial variability of rainfall, determining how much water plants lose to the atmosphere becomes fundamental in irrigation planning, which considers the evapotranspiration demand of each species (VELLAME et al., 2012).

Generally, the water demand of plants is determined indirectly, by estimating their evapotranspiration through the quantification of the total losses of water to the atmosphere (SCHMIDT et al., 2013), since the weighing lysimeters, for being difficult to operate and install, are used only in experimental research.

In the literature, information on the water demand of cocoa plants is scarce, but necessary, especially when the intention is to work with irrigated crops. Thus, weighing lysimeters, if well operated and calibrated, reliably determine the water needs of agricultural crops (SILVA et al., 2019), which according to Lima et al. (2011), vary between the stages of growth and development, being considered through their crop coefficients $(\mathrm{Kc})$.

This makes lysimetry a technique to be used more frequently in studies that seek information about the water consumption of agricultural crops, being considered excellent in the direct measurements of crop evapotranspiration and reference evapotranspiration (HOWELL et al., 1995; FLUMIGNAN et al., 2011; NASCIMENTO et al., 2011; SILVA et al., 2019).

Lysimetry has the advantage of determining water consumption by plants in a period of less than one day and, with this, crop coefficients can be better determined at all stages of the crop. This justifies the various types of lysimeters with different sizes, materials and even shapes, which are cited in the literature (CAMPECHE et al., 2011; NASCIMENTO et al., 2011; REICHARDT; TIMM, 2012; SILVA et al., 2019).

According to Nascimento et al. (2016), before using any lysimeter, a careful analysis should be performed, especially of the weighing mechanisms, in order to know and quantify the errors attributed to the instruments, which in turn are related to the load cells, cables, data collection system and the structure itself to be weighed.

Thus, the calibration of the weighing lysimeter is the most important step of a study that aims to use this instrument to reliably measure the evapotranspiration of agricultural crops and to determine crop coefficients. It can be performed before and during the use of lysimeters, being useful in making decisions about the data that should or should not be used in the computation of evapotranspiration.

In view of the above, the study aimed to determine performance parameters of a weighing lysimeter and evaluate its adequacy for the direct determination of cocoa crop evapotranspiration.

\section{MATERIAL AND METHODS}

The study was carried out in an area of 4,868.9 $\mathrm{m}^{2}$ of the Graduate Program in Agricultural Engineering of the Universidade Federal do Recôncavo da Bahia (UFRB), in the municipality of Cruz das Almas, Bahia, Brazil, with geographic coordinates $12^{\circ} 40^{\prime} 12^{\prime \prime} \mathrm{S}$ and $39^{\circ} 6^{\prime} 7^{\prime \prime} \mathrm{W}$, and average altitude of $220 \mathrm{~m}$.

According to the Köppen-Geiger classification (KOTTEK et al., 2006), the climate of the region is of Am type, hot humid tropical, in which the driest period occurs from September to March and the highest concentration of rains occurs from April to August. The average annual rainfall is $1,170 \mathrm{~mm}$ with variations between 800 and 1,400 $\mathrm{mm}$, relative air humidity of $80.0 \%$, average annual temperature around $24.5^{\circ} \mathrm{C}$ and average wind speed of $3.1 \mathrm{~m} \mathrm{~s}^{-1}$ (GUIMARÃES et al., 2016).

The soil of the experimental area was classified as Latossolo Amarelo Distrocoeso, with sandy loam texture, according to the Brazilian Soil Classification System (SANTOS et al., 2018) and, with correlated classification of Typic Haplustox in Soil Taxonomy (SOIL SURVEY STAFF, 2014) and Ferralsol in WRB/FAO (2015).

The weighing lysimeter was installed in the center of a cocoa plantation and is composed of a metal carbon steel tank, with dimensions of $1.20 \mathrm{x}$ $1.20 \times 1.20 \mathrm{~m}$, totaling a surface area of $1.44 \mathrm{~m}^{2}$ (Figure 1).

The lysimeter was installed after the manual excavation of the soil. In order to avoid the collapse of the side walls, they were lined with a 0.15 -m-thick layer of reinforced mortar. The bottom space between the internal and external tanks was lined with a layer of crushed stone to favor rainwater drainage between the two tanks. The lysimeter was filled with the soil removed from the excavation site itself, maintaining the sequence and depth of the original horizons.

A 0.05-m-diameter PVC pipe was installed under a layer of crushed stone in the internal tank to drain excess water in the lysimeter during irrigation and precipitation events, in order to avoid reduction in soil aeration (Figure 1B). 
(A)

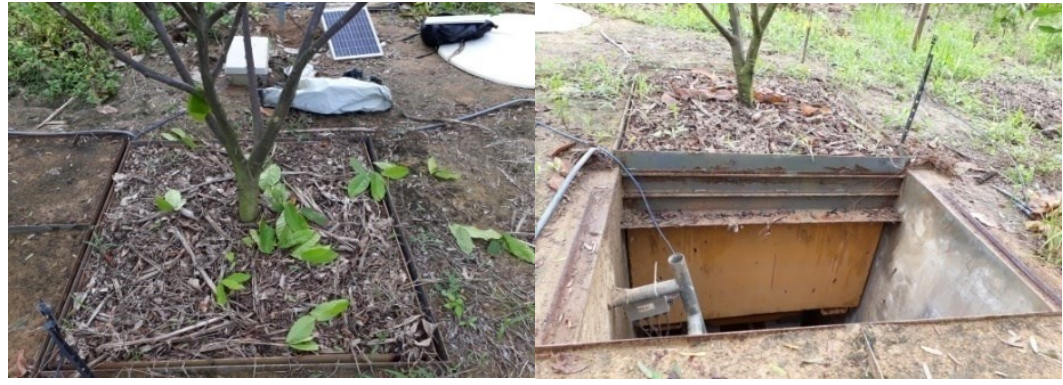

(B)

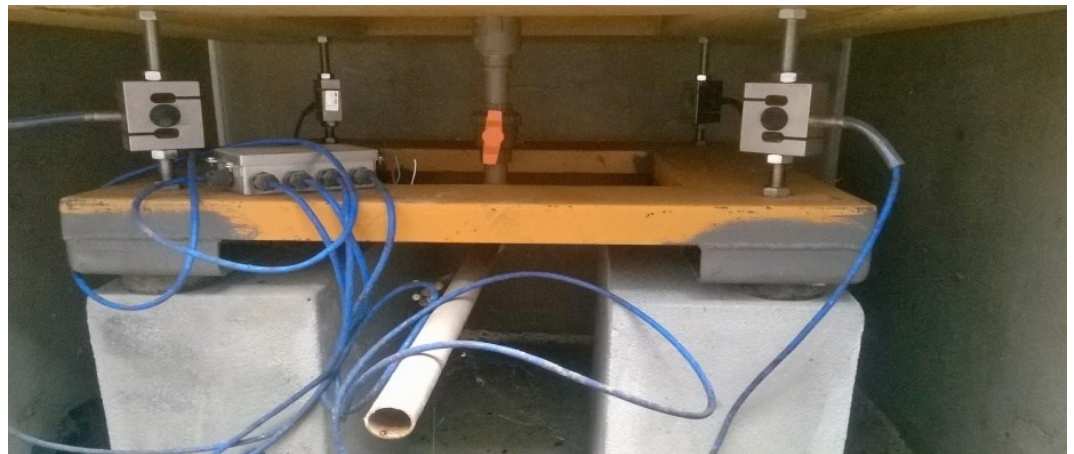

Figure 1. Cultivation of clonal cocoa - CCN 51 in a lysimeter box (A) installed on four load cells (B).

The support for the sensitive elements of the lysimeter (load cells) was constructed using rectangular metal structures with 150 -mm-wide "U" beams, in the dimensions of $0.79 \mathrm{~m} \times 0.55 \mathrm{~m}$ supported on four concrete footings, with diameter of $0.15 \mathrm{~m}$ and height of $0.20 \mathrm{~m}$. Four load cells, Z-1T model from Alfa Instruments, were screwed onto the structure. These load cells had an individual capacity of $1000 \mathrm{~kg}$ and, according to the manufacturer, sensitivity of $2 \mathrm{mV} \mathrm{V}^{-1} \pm 0.1 \%$ of approximately 10,000 divisions corresponding to $0.1 \mathrm{~kg}$, combined error of $0.03 \%$ of the end of scale and recommended input range of $10 \mathrm{mV} \mathrm{V}^{-1}(0.00033 \mathrm{mV}$ resolution). The total capacity of the four load cells of $4000 \mathrm{~kg}$ corresponds to the balance output of $13.2 \mathrm{mV}$.

A datalogger (CR1000, Campbell Sci) was installed near the lysimeter for data storage. The datalogger performed readings every 01 second and was set to store the averages of the measurements of the four load cells every 15 minutes. After that, these stored data were transferred to a computer. The electrical power to power the system was supplied by a $12 \mathrm{~V}$ battery, coupled to a solar panel.

The calibration of the lysimeter cultivated with one cocoa plant in full development was performed in the absence of sunlight, from 3:00 a.m., avoiding soil evaporation at high temperatures, as it was not possible to cover the surface of the lysimeter with plastic tarpaulin. In addition, the oscillations in measurements due to wind turbulence are also minimized at this time. The test was conducted using 41 plastic bags containing known masses of 0.05 , $0.10,0.144,0.20,0.250,0.30,0.30,0.40,0.50$, $0.720,1.44,2.88,5.0,10.0$ and $20.0 \mathrm{~kg}$ of crushed stone no. 1. Three bags were prepared for each weight, except for $2.88 \mathrm{~kg}$, which corresponded to only two bags. All were weighed on a precision electronic scale and subsequently sealed.

Calibration was performed with the addition and removal of standard masses on the lysimeter surface. At each mass increment, 2 minutes were allowed for stabilization of the reading performed in the datalogger connected to the load cells, and then the electrical signal $(\mathrm{mV})$ generated by their deformation was recorded. The reverse process was also performed, removing the bags in the same order and time intervals as they were added to the system, generating 81 ordered pairs $(\mathrm{mV} \times \mathrm{kg})$ for each of the five loading and unloading cycles that simulate the inputs and outputs of liquid mass in the lysimeter set.

After obtaining the readings, a linear regression statistical analysis was performed using a spreadsheet of Microsoft Office Excel 2010 software, making it possible to establish a linear relationship between additions and removals of the standard masses $(\mathrm{kg})$ with the output signal of the load cells in $\mathrm{mv}(\mathrm{mV})$ per excitation volt, where each electrical signal emitted resulted from the sum of the four load cells. This step made it possible to evaluate the adequacy of the method for the direct measurement of cocoa ETc based on the parameters precision, accuracy, sensitivity, resolution, repeatability, hysteresis and uncertainty. The errors in mass unit were presented as a percentage of the end of scale $(\% \mathrm{ES})$.

Precision was determined by calculating the standard error of linear regression estimate and the Willmott's index of agreement (WILLMOTT, 1981). Accuracy was determined by the maximum deviation 
obtained between the mass applied in the lysimeter and its reading converted into mass for all loading and unloading cycles. Sensitivity was obtained by observing the lowest variation of the signal in $\mathrm{mV}$ in the loading and unloading cycles in the calibration process, being confirmed by observing the smallest mass variation converted into water depth for an interval of one hour for a day with rain and drainage. Resolution is inherent in the lysimeter-load celldatalogger set. Repeatability was determined based on the greatest deviation between values in successive measurements for a given standard weight. Hysteresis was calculated by the maximum difference in all reading cycles between measurements taken in ascending and descending order for the same mass value. Uncertainty was obtained according to the methodology proposed by Gonçalves Jr (2004), through equation 01.

$$
\mathrm{U}=\frac{\frac{\sigma . \mathrm{t}}{\sqrt{\mathrm{n}}}}{\mathrm{C}}
$$

where, $U$ is the uncertainty of the measurements taken in the lysimeter; $t$ is the Student's coefficient for the measurements of the five loading and unloading cycles at $95 \%$ reliability; $\mathrm{n}$ is the number of measurements and $\mathrm{C}$ is the value of the variable.

Cocoa ETc was calculated by equation 02 (CAMPECHE, 2002), in which the mass variation (Equation 03) of the lysimeter in days with the absence of precipitation and irrigation events is negative and represents the loss of water to the atmosphere by evapotranspiration, since the current mass is lower than the previous mass detected in the weighing system.

$$
\begin{gathered}
\mathrm{ETc}=\mathrm{P}+\mathrm{I} \pm \frac{\Delta \mathrm{ML}}{\mathrm{A}}-\mathrm{D} \\
\Delta \mathrm{ML}=\mathrm{M}_{\mathrm{i}}-\mathrm{M}_{\mathrm{i}-1}
\end{gathered}
$$

where, ETc is crop evapotranspiration $(\mathrm{mm})$; $\mathrm{P}$ is precipitation $(\mathrm{mm})$; I is the water depth applied via irrigation systems $(\mathrm{mm}) ; \Delta \mathrm{ML}$ is the mass variation of the lysimeter $(\mathrm{kg})$; $\mathrm{A}$ is the area of the lysimeter $\left(\mathrm{m}^{2}\right)$; $\mathrm{D}$ is drainage $(\mathrm{mm}) ; \mathrm{M}_{\mathrm{i}}$ is the current mass of the set and $\mathrm{M}_{\mathrm{i}-1}$ is the previous mass of the set for the time period considered.

\section{RESULTS AND DISCUSSION}

The results for the calibration of the weighing lysimeter in this study are shown in Figure 2. The linear model adequately described the relationship between the masses in the addition and removal processes and the output signal of the load cells. The correlation was above 0.99 with standard error of the estimate on the order of $0.042 \mathrm{~kg}$ or $0.03 \mathrm{~mm}$, and calibration curve slope of $524.69585 \mathrm{~kg} \mathrm{mV}^{-1}$ or $0.002 \mathrm{mV} \mathrm{kg}{ }^{-1}$, indicating the sensitivity of the measuring system and datalogger according to Schmidt et al. (2013).

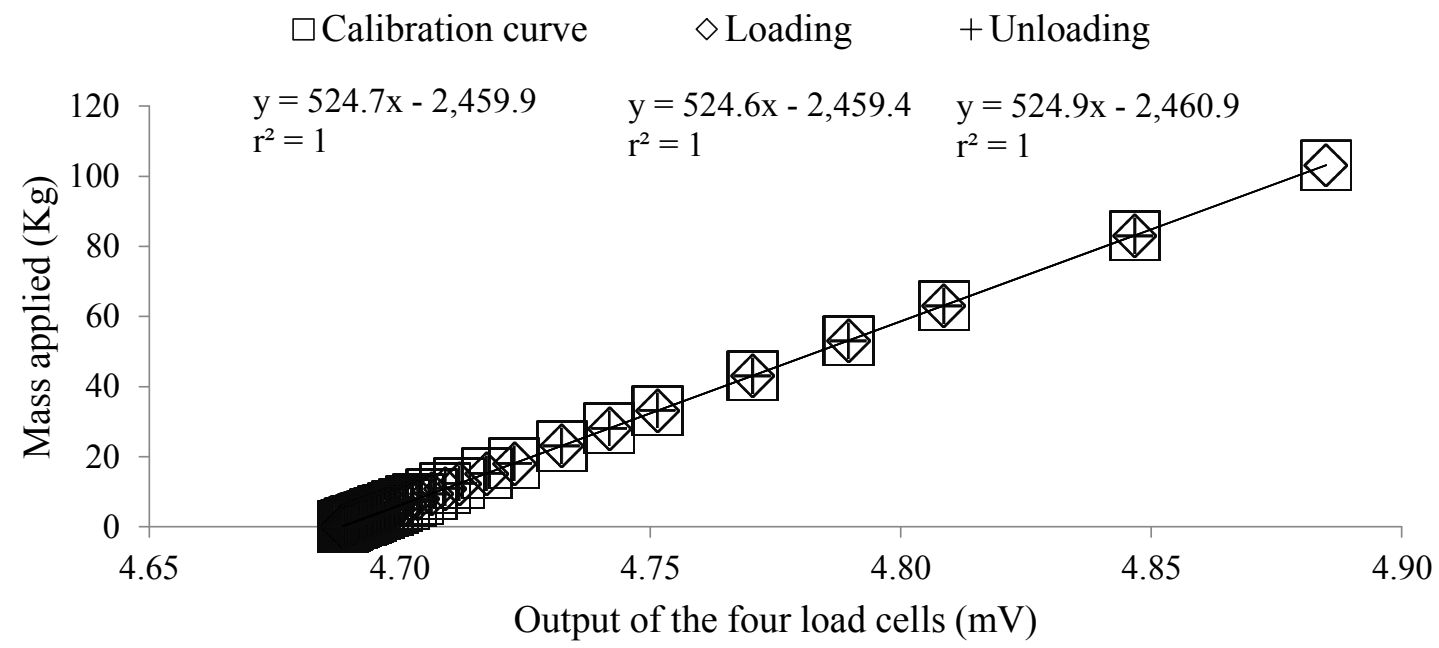

Figure 2. Scale response to the additions and removals of masses applied on the lysimeter.

The linear model also describes very well the relationship between additions and removals of the standard masses and the masses measured, with correlation values greater than 0.99 (Figure 3). In addition, the Willmott's index of agreement $d=1$, calculated for the total set of data, shows the excellent performance of the instrument in generating data with low dispersion in repetitive measurements. 


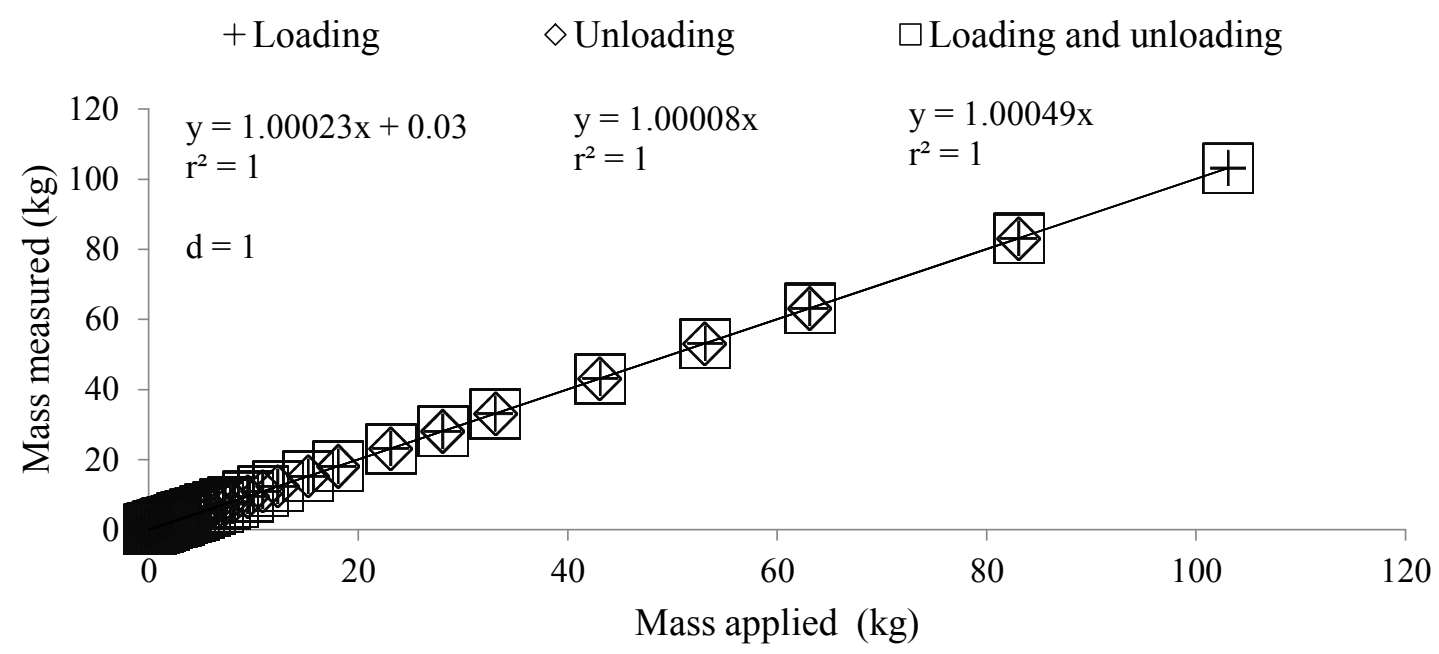

Figure 3. Relationship between mass applied and measured in the loading and unloading cycles in the calibration of the lysimeter with one young cocoa plant.

The high coefficients of determination obtained in the calibration curves and the standard error of the linear regression estimate show that the weighing lysimeter of the present study has high precision, similar to that obtained by Schmidt et al. (2013) who obtained a standard error of $0.03 \mathrm{~mm}$ when calibrating a weighing lysimeter to study the water demand of tobacco (Nicotiana tabacum L.).

However, when comparing the results of this study with those of other calibrations, the accuracy was high. Carvalho et al. (2013) obtained standard errors of the estimate of $0.2,0.08$ and $0.66 \mathrm{~mm}$ when calibrating three weighing lysimeters to determine the evapotranspiration of coffee crop in UberlândiaMG. Campeche et al. (2011) and Mendonça et al. (2007) obtained accuracies of $0.228 \mathrm{~mm}$ and $0.09 \mathrm{~mm}$, respectively, when calibrating a large weighing lysimeter. Faria, Campeche and Chibana (2006) obtained a standard error between $0.07 \mathrm{~mm}$ and $0.42 \mathrm{~mm}$ when calibrating 10 weighing lysimeters.

The combination of the errors associated with the system during calibration of $\pm 0.1 \mathrm{~kg}$ is consistent with the information provided by the manufacturer. And these errors are the ones that best qualify the method, since the uncertainty of the measurements cannot be visualized with the regression analysis, which so little expresses the accuracy of the measurements performed by it. This parameter is strongly influenced by linearity errors, which in the calibration process of this study are those of repeatability (maximum deviation and uncertainty at 95\%). According to Vellame et al. (2012), these repeatability errors are affected by uncontrolled factors in the calibration process and cannot be compensated or corrected by the calibration curve.

Figure 4 shows that the measurement system has an accuracy of $\pm 0.18 \mathrm{~kg}$, representing a percentage of the end of scale (ES) of $\pm 0.16 \%$, equivalent to $\pm 0.11 \mathrm{~mm}$, very close to the value obtained by Schmidt et al. (2013), equal to $0.23 \mathrm{~kg}$, equivalent to the percentage of $0.21 \%$ (ES) or $0.13 \mathrm{~mm}$.

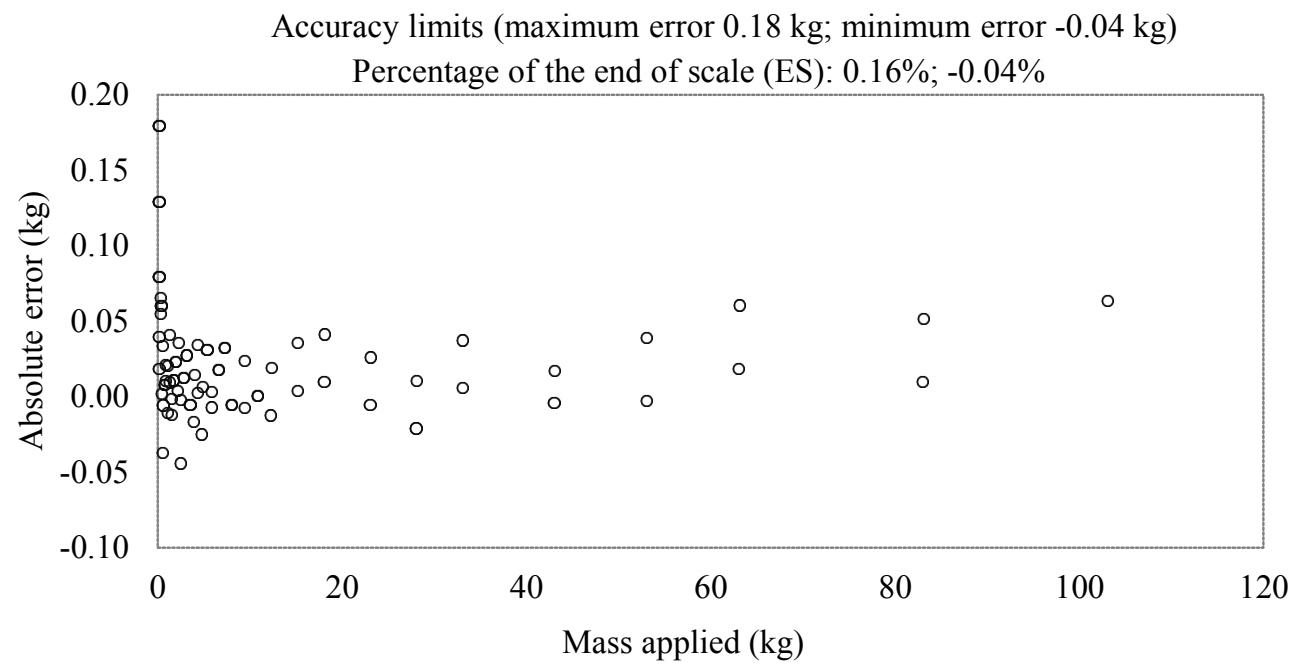

Figure 4. Error between masses measured and applied during the calibration of the weighing lysimeter cultivated with one young cocoa plant.

Rev. Caatinga, Mossoró, v. 33, n. 3, p. 803 - 814, jul. - set., 2020 
Accuracy, despite being an indicator of the performance parameter of the method that is usually influenced by parameters that cannot be controlled, was little influenced by them. The combination of errors obtained in this calibration process is within acceptable limits of $\pm 0.1 \mathrm{~kg}$ or $\pm 0.07 \mathrm{~mm}$, very close to that obtained by Campeche et al. (2011) of $0.08 \mathrm{~mm}$
In Figure 5, it is possible to observe that errors of repeatability, uncertainty $(95 \%)$ and hysteresis are on the order of $0.044 \mathrm{~kg}, 0.22 \mathrm{~kg}$ and $0.031 \mathrm{~kg}$, respectively, and the percentage of these errors is within acceptable limits, since each load cell at its maximum capacity has a combined error of $\pm 0.03 \%$ (ES)
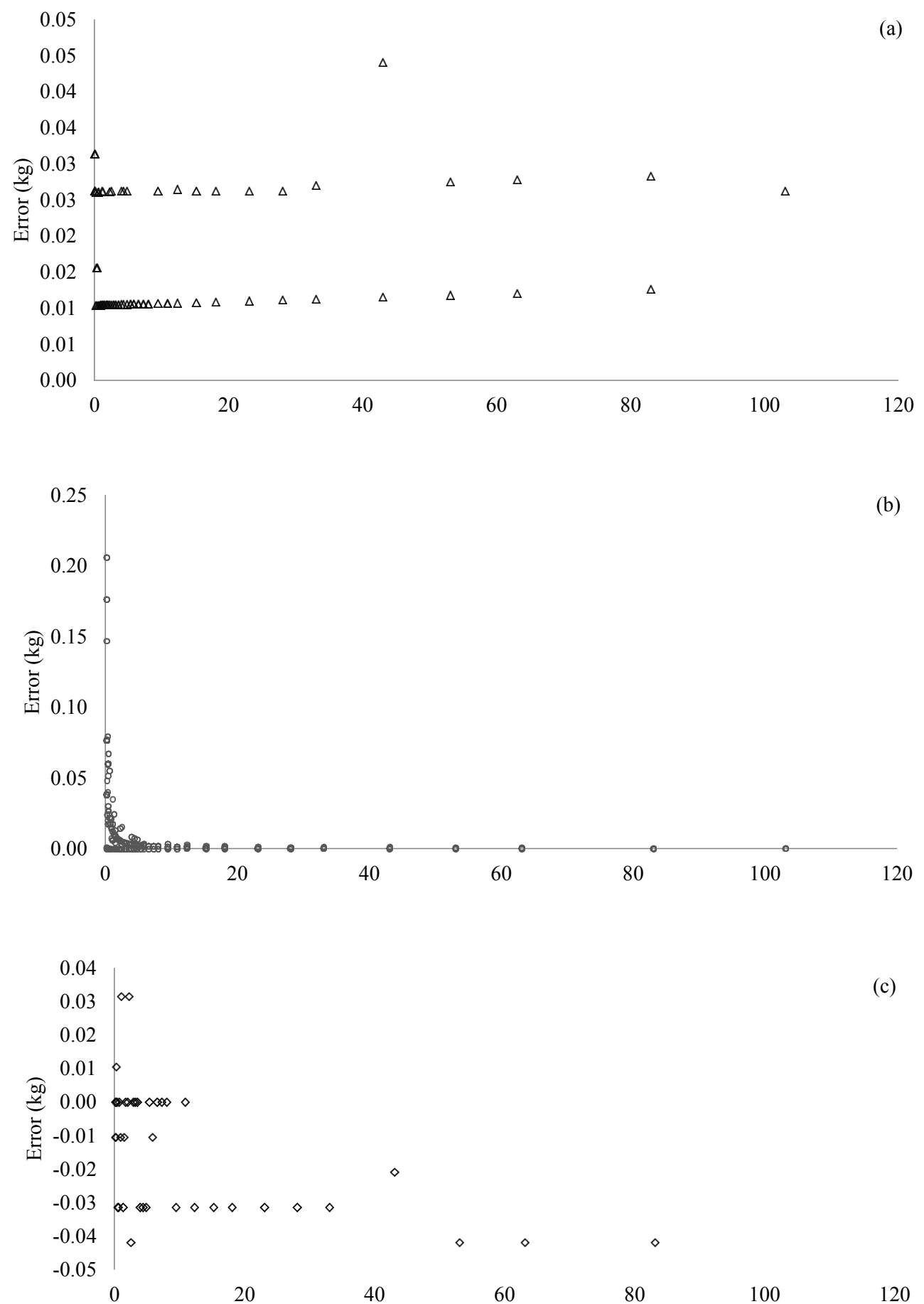

Mass applied (kg)

Figure 5. Errors of repeatability (a), uncertainty at $95 \%$ (b) and hysteresis (c) in obtaining the masses measured in relation to the masses applied in the calibration of the weighing lysimeter, cultivated with one young cocoa plant. 
The repeatability error of $0.044 \mathrm{~kg}$ obtained in the calibration of the lysimeter set of this study representing $0.04 \%$ (ES) or $0.03 \mathrm{~mm}$ is similar to that reported by Vellame et al. (2012), who obtained $0.023 \%$ and $0.042 \%$ (ES) when calibrating two weighing lysimeters, and lower than that obtained by Schmidt (2008) of $0.18 \%$ (ES).

The hysteresis error of $0.031 \mathrm{~kg}$, representing $0.03 \%$ (ES) or $0.02 \mathrm{~mm}$, is similar to those reported by Vilela et al. (2015), who obtained $0.02 \mathrm{~kg}$ when calibrating a mini weighing lysimeter, and by Vellame et al. (2012), who obtained $0.019 \%$ and $0.015 \%$ (ES). These errors were virtually the same. The low dispersion can be associated with all the care taken in the operation of the system throughout the calibration process, such as the addition and removal of the masses, the interval used for stabilization of the readings and the time at which they were performed, in order to minimize the external effects as much as possible.

Therefore, without major errors and with a high precision, the lysimeter of the present study has excellent performance and can be used to perform measurements with reliability, since the measurements showed uncertainty of $0.22 \mathrm{~kg}$. According to Allen et al. (2011) for load cells the expected values of uncertainty are within a range from 5 to $15 \%$, and assuming the percentage value of end of scale of $0.19 \%$ for the measurements in this calibration process, the chosen method has measurement uncertainty within expected.

In addition, load cells operate at a resolution of $0.33 \mu \mathrm{V}$ or $0.00033 \mathrm{mV}$, corresponding to 0.150 $\mathrm{kg}$ or $0.10 \mathrm{~mm}$, detected in the datalogger during the calibration process. The smallest variation of the signal observed in the lysimeter capable of causing a change in the measurement was also observed with the addition of the $150 \mathrm{~g}$ mass. According to the results obtained in the calibration, the scale has sensitivity capable of detecting mass variation of $\pm 0.1 \mathrm{~mm}$. In practice, these values were confirmed by means of the measurements taken at 1 hour intervals in the period of 24 hours (Figure 6).

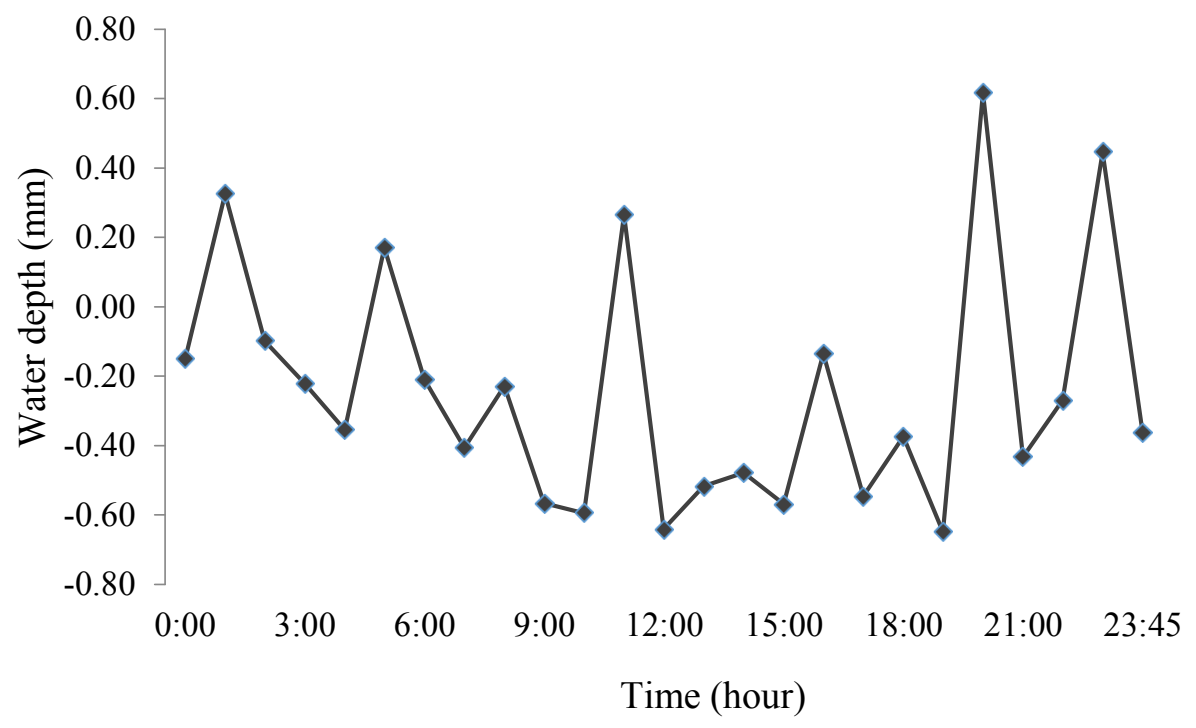

Figure 6. Sensitivity in the lysimeter set to mass changes during a day with precipitation and drainage for August 1, 2017.

In practice, the sensitivity determined by this system was $-0.09 \mathrm{~mm}$, lower than that determined by Nascimento et al. (2011), $0.00001 \mathrm{~mm}$, and higher than that determined by Campeche et al. (2011), $0.19 \mathrm{~mm}$. Thus, the sensitivity obtained in this lysimeter is within acceptable limits because, according to these researchers, instruments whose sensitivity is very high are subject to some problems, when operated in the field and with tall plants, such as the wind effect, which produces instantaneous oscillations in the measurements.

After evaluating the performance of the method, confirming its capacity to determine cocoa crop water consumption with reliability, mass variations were determined and the cocoa crop evapotranspiration was calculated for days without the occurrence of precipitation and irrigation events and for days with records of precipitation events (Figure 7 and 8).

The mass variations at 1-hour intervals detected on March 1, 2017, without the occurrence of precipitation and irrigation events, show that the reduction in masses during the day was higher than during the night period, due to the evaporative demand, which was also higher in this period (Figure 7a), remaining more constant during the night. Wind speed is also a factor that influenced the measurements, and for this day an average of $2.8 \mathrm{~m} \mathrm{~s}^{-1}$ was observed, with a peak of $5.7 \mathrm{~m} \mathrm{~s}^{-1}$ at 17:00 h (Figure 7b). 
(a) $\curvearrowright$ Mass $\longrightarrow$ Radiation

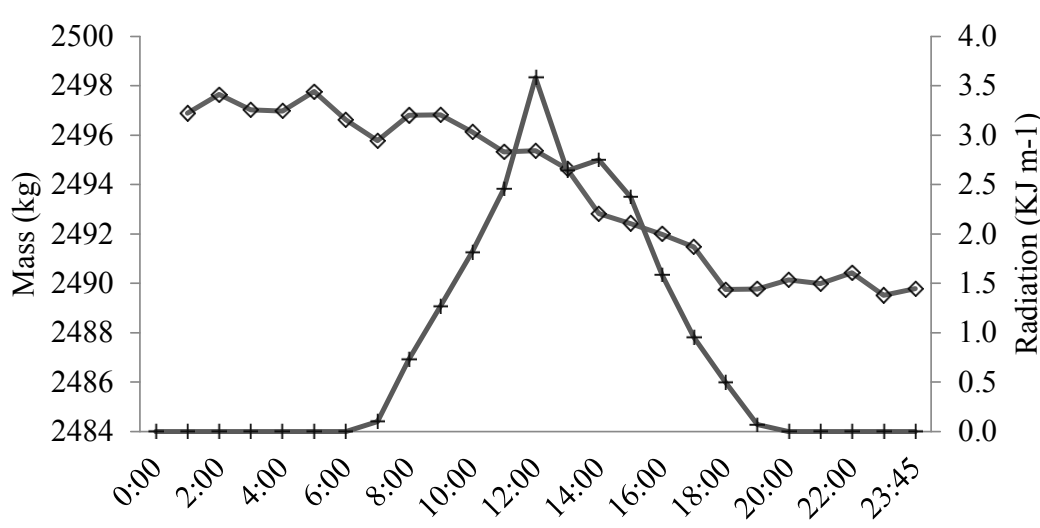

(b) $\prec$ Mass $\longrightarrow$ Wind speed

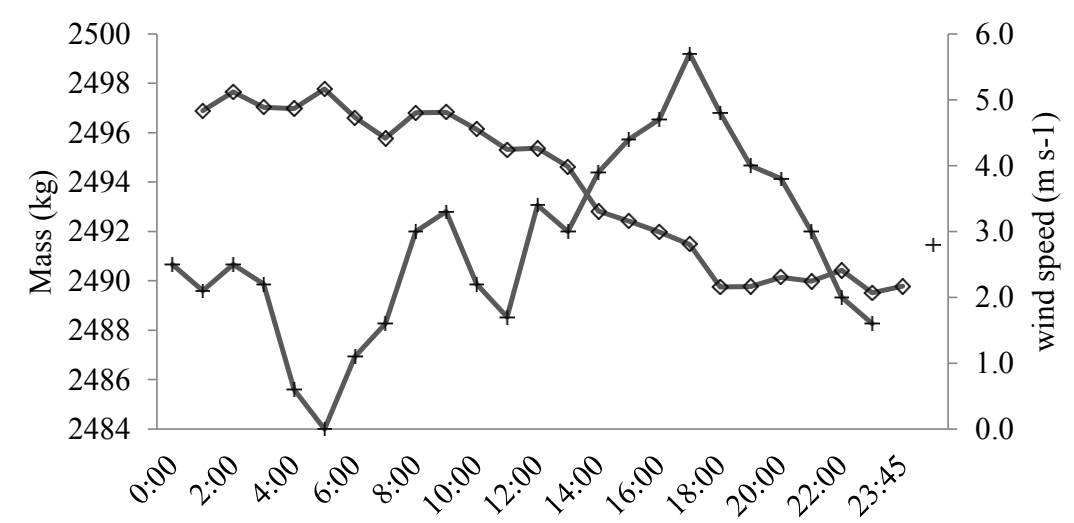

(c)
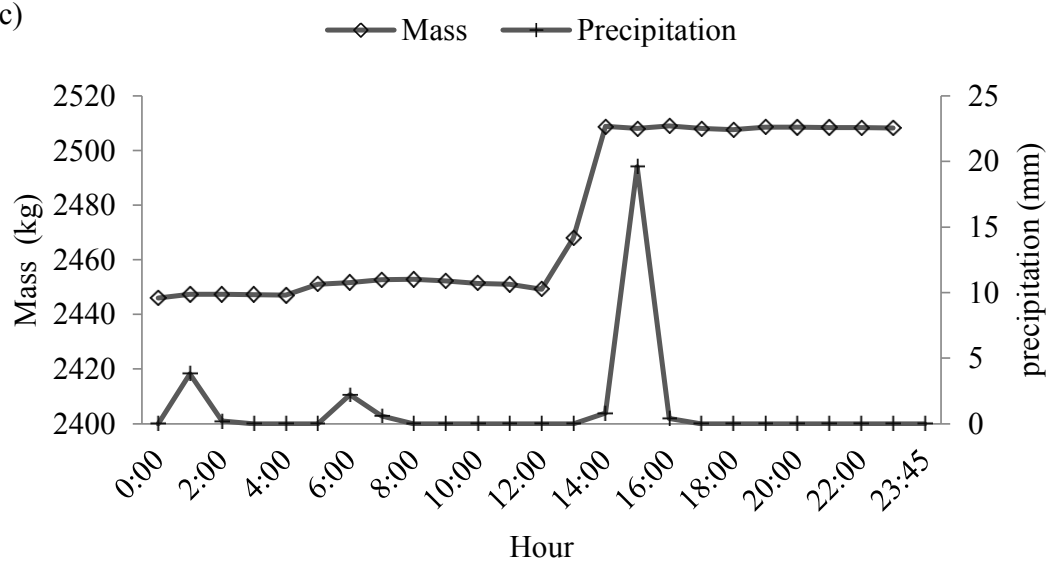

Figure 7. Mass variation in the lysimeter on March 1, 2017, without the occurrence of precipitation and irrigation as a function of the meteorological conditions radiation (a) and Wind speed (b), and mass variation on March 18, 2017, with precipitation (c) and constant drainage.

The results of the present study corroborate those reported by several researchers, who found negative effects caused by wind oscillations in lysimeter measurements (PRUITT; ANGUS, 1960; VAN BAVEL; MYERS, 1962; ROSENBERG, 1969; BERGAMASCHI et al., 1997; CAMPECHE,
2002; CAMPECHE et al., 2011; NASCIMENTO et al., 2011), so it is more recommended to increase the data collection interval in order to minimize them (HOWELL et al., 1995).

Besides wind speed, another limiting factor for the correct measurement of liquid mass 
measurements in the system are precipitation and drainage events. The analysis of lysimeter operation (Figure 7c) showed a peak in the curve due to liquid mass inputs in the system, which occurred during this day. These events influenced the mass measurements, and increasing variations were observed throughout the day. Therefore, it is recommended to eliminate the days with precipitation and drainage, because there is no way to separate the outputs through crop evapotranspiration from those through drainage. In the present study, these days were only used to evaluate the functioning of the lysimeter on atypical days.

In the literature, some researchers such as Nascimento et al. (2011), Lima et al. (2013), Nascimento et al. (2016) and Santos et al. (2017) also noticed that evapotranspiration measurements taken in weighing lysimeters were influenced by the events of constant precipitation throughout the day.

Figure 8 shows the measurements of depths evapotranspired by cocoa crop over one day, with and without precipitation records, and a trend of reduction in the values during the night period was observed.

This behavior is justifiable due to the atmospheric demand and, among the factors, solar radiation is the one with greatest influence because, in the night time, after sunset, it becomes zero, not being sufficient to provide the necessary energy to causes large outputs of water mass from the system, which ultimately become dependent on other factors such as the aerodynamic conditions of the air and the energy accumulated by the system itself (NASCIMENTO et al., 2011).

(a)
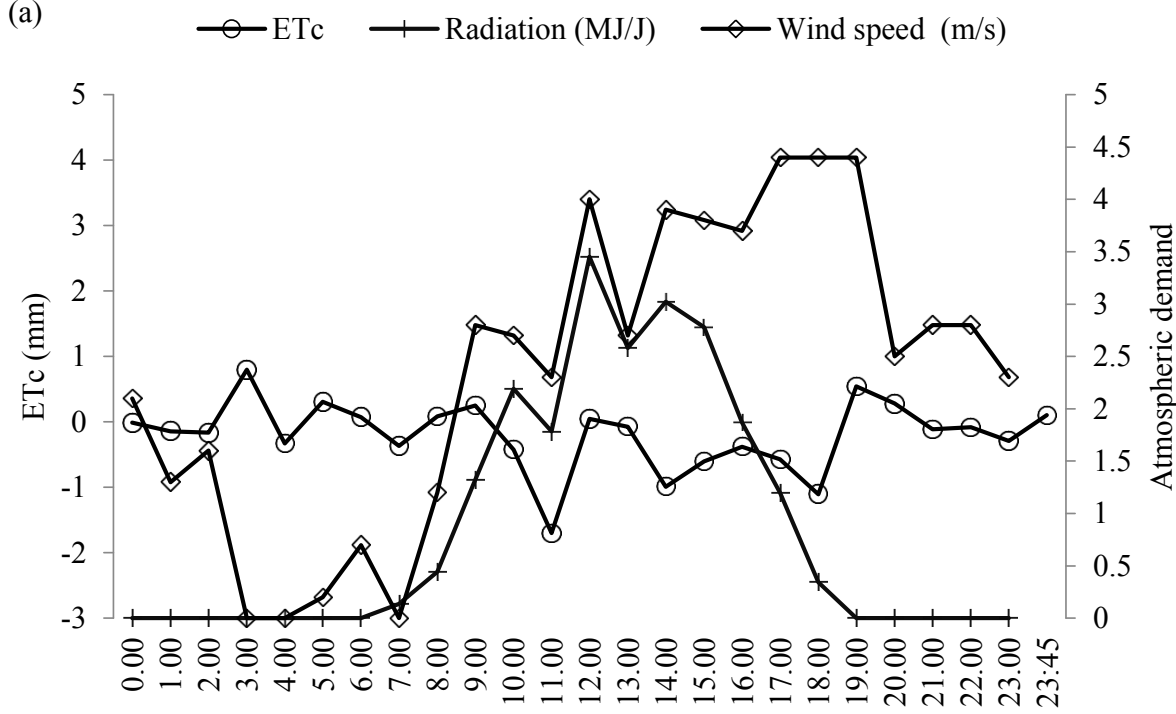

(b)
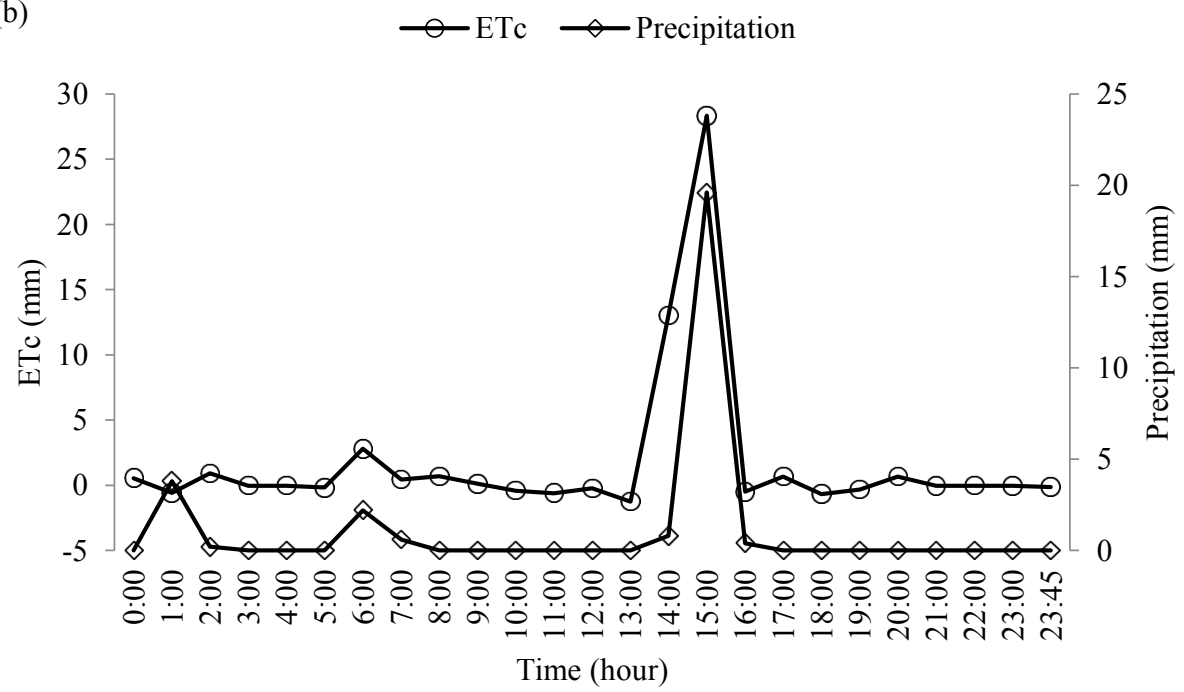

Figure 8. Evapotranspired depth by the cocoa plant at 1-hour intervals for October 2, 2017, with absence of precipitation and irrigation as a function of the evaporative demand of air (a), and evapotranspired depths for March 18 with constant irrigation and drainage (b).

Rev. Caatinga, Mossoró, v. 33, n. 3, p. 803 - 814, jul. - set., 2020 
Figure 8a shows that this trend did not occur during the entire period in which global solar radiation was zero, and it was possible to observe an increase in the values of mass output between 0:00 and 5:00 $\mathrm{h}$ and after 18:00 pm. Wind turbulence influences ETc measurements, and the oscillations were equal to $0.0 \mathrm{~m} \mathrm{~s}^{-1}$ at $3: 00 \mathrm{~h}$ and $4.4 \mathrm{~m} \mathrm{~s}^{-1}$ at 17:00, 18:00 and 19:00 $\mathrm{h}$ (Figure 8a). Therefore, the aerodynamic power of the air is one of the factors that most influenced the mass outputs of the system at night.

In order to emphasize how much the atmospheric demand influences the evapotranspiration process, when comparing the two periods, the highest ETc values measured occurred precisely during the day, and mass outputs of up to $1.7 \mathrm{~mm}$ were recorded at 11:00 $\mathrm{h}$.

In the literature, some authors have also observed that evapotranspiration follows the trend of atmospheric demand. Pruitt and Angus (1960), Van Bavel and Myers (1962), Rosenberg (1969), Bergamaschi et al. (1997), Santiago (2001) Campeche (2002) and Campeche et al. (2011) verified variations in ETc measurements caused by wind in their lysimeters.

The influence of radiation on ETc measurements by lysimetry was observed by Pereira et al. (2002), who obtained approximately $85 \%$ of the values in the daytime period when determining ETc, and Campeche et al. (2011), who observed a small percentage of liquid mass outputs in the night period on both days, due to the aerodynamic power of the air, when analyzing the functioning of weighing lysimeters determining the mass variation in two atypical days, with and without precipitation.

In addition to the advective and evaporating power of the air (wind and radiation), precipitation also influences the ETc measurements performed with weighing lysimeters. In the present study, they were strongly affected by the precipitation events.

An analysis was performed in Figure $8 b$ to determine the ETc on a day with constant precipitation and drainage, and positive values of water depth were observed during the evaluated period, which correspond to the inputs of liquid mass in the lysimeter set.

The largest mass inputs in the system occurred in the daytime (Figure $8 \mathrm{~b}$ ), caused by the highest precipitations recorded for the day considered. Mass output was also observed in all periods, day and night, showing values considered high for the day and especially during the night, when there is not enough radiation to evaporate such large masses of water, even if the evapotranspiring surface absorbed an energy of $2.45 \mathrm{MJ}$, which is equivalent to the energy used to evaporate $1.0 \mathrm{~mm}$ of water (PEREIRA; SEDYAMA; VILLA NOVA, 2013), so these are probably drained water depths.

In the present study, the results showed that, on days without and with the occurrence of precipitation events, the behaviors of the data are completely different. On rainy days there is an increase/decrease of mass in the system, and the calculation of the water depth does not correspond to the volume evapotranspired by the crop. On nonrainy days, the decrease of mass in the system occurs along the entire evaluated period, and the water consumption by the crop can be observed over the evaluated period. On the days evaluated, March 1 and October 2 (Figure $7 \mathrm{a}, 7 \mathrm{~b}$ and $8 \mathrm{a}$ ), without precipitation and irrigation, and on March 18 (Figures $7 \mathrm{c}$ and $8 \mathrm{~b}$ ), with precipitation and drainage, the water depths measured in the lysimeter were $4.43 \mathrm{~mm},-4.48 \mathrm{~mm}$ and $42.27 \mathrm{~mm}$, respectively.

Although weighing lysimeters are efficient instruments for accurately determining evapotranspiration, some meteorological variables such as precipitation ultimately hamper the monitoring of water consumption of the crop, when ETc measurements are performed by mass balance. Thus, even if the system has excellent precision, accuracy and resolution, care should be taken in its operation and in the processing of the data.

\section{CONCLUSIONS}

The lysimeter presented here is technically suitable for the direct determination of cocoa ETc, with excellent accuracy, resolution and sensitivity capable of detecting small changes in mass at time intervals of less than 1 hour.

\section{ACKNOWLEDGMENTS}

The authors would like to thank the Fundação de Amparo à Pesquisa do Estado da Bahia-FAPESB, for granting a Doctoral Scholarship; Coordenação de Aperfeiçoamento de Pessoal de Nível SuperiorCAPES; the Universidade Federal do Recôncavo da Bahia-UFRB; the Postgraduate Program in Agricultural Engineering, for supporting research; Professors Lucas Melo Vellame, for the support and guidance in the installation and operation of the system and Maurício Antônio Coelho Filho, for the guidance in the data analysis process and writing the document.

\section{REFERENCES}

ALLEN, R. G. et al. Evapotranspiration information reporting: I. Factors governing measurement accuracy. Agricultural Water Management, 98: 899-920, 2011.

BERGAMASCHI, H. et al. Automação de um lisímetro de pesagem através de estação 
meteorológica, a campo. In: CONGRESSO BRASILEIRO DE AGROMETEOROLOGIA, 10, 1997, Piracicaba. Anais... Piracicaba: SBA, 1997. p. 222-224.

CAMPECHE, L. F. S. M. et al. Lisímetro de pesagem de grande porte. Parte I: Desenvolvimento e calibração. Engenharia Agrícola e Ambiental, 15: 519-525, 2011.

CAMPECHE, L. F. S. M. Construção, calibração e análise de funcionamento de lisímetros de pesagem para determinação da evapotranspiração da cultura da lima ácida "Tahiti" (Citruslatifolia Tan.). 2002. 67 f. Tese (Doutorado em Agronomia: Área de Concentração em Irrigação e Drenagem) - Escola Superior de Agricultura "Luiz de Queiroz" - Universidade de São Paulo, Piracicaba, 2002.

CARVALHO, H. P. et al. Desenvolvimento de lisímetros de pesagem na cultura do café. Bioscience Journal, 29: 1750-1760, 2013.

FARIA, R. T.; CAMPECHE, F. S. M.; CHIBANA, E. Y. Construção e calibração de lisímetros de alta precisão. Revista Brasileira de Engenharia Agrícola e Ambiental, 10: 237-242, 2006.

FLUMIGNAN, D. L. Lisímetros de pesagem direta para o estudo do consumo hídrico do pinhão manso (Jatrophacurcas L.). 2011. 202 f. Tese (Doutorado em Agronomia: Área de Concentração em Irrigação e Drenagem) - Escola Superior de Agricultura "Luiz de Queiroz", Universidade de São Paulo, Piracicaba, 2011.

FOOD AND AGRICULTURE ORGANIZATION FAO. World reference base for soil resources 2014: International soil classification system for naming soils and creating legends for soil maps. Rome, 2015. $192 \mathrm{p}$.

GONÇALVES JR, A. A. Laboratório de Metrologia e Automatização Departamento de Engenharia Mecânica. Apostila de metrologia Parte 1. 1. ed. Florianópolis, SC. 2004. 120 p.

GUIMARÃES, M. J. M. et al. Balanço hídrico para diferentes regimes pluviométricos na região de Cruz das Almas-BA. Ciências Agrárias, 59: 252-258, 2016.

HOWELL, T. A. et al. Calibration and scale performance of Bushland weighing lysimeters. Transactions of the ASAE, 38: 1019-1024, 1995.

KOTTEK, M. et al. World Map of the KöppenGeiger climate classification updated. Meteorologische Zeitschrift, 15: 259-263, 2006.
LIMA, D. P. et al. Evapotranspiração real diária em sub-bacias do Paracatu, utilizando produtos do sensor Modis. Ceres, 61: 17-27, 2014

LIMA, N. S. et al. Desempenho de um lisímetro de pesagem hidráulica com transdutor de pressão hidrostática e sistema manométrico. Irriga, 18: 540$557,2013$.

LIMA, J. R. S. et al. Balanço de energia e evapotranspiração de feijão caupi sob condições de sequeiro. Ciência Agronômica, 42: 65-74, 2011.

MENDONÇA, J. C. et al. Determinação do coeficiente cultural $(\mathrm{Kc})$ do feijoeiro (Phaseolus vulgaris L.), em Campos dos Goytacazes - RJ. Revista Brasileira de Engenharia Agrícola e Ambiental, 11: 471-475, 2007.

NASCIMENTO, A. H. C. et al. Desempenho de um lisímetro de pesagem hidráulica com diferentes sistemas de leitura. Irriga, 13: 232- 245, 2016

NASCIMENTO, E. F. do. et al. Construção e calibração de lisímetros de pesagem para determinação da evapotranspiração e coeficiente de cultivo em videira de vinho cv. Syrah. Irriga, 16: 271-287, 2011.

PEREIRA, A. R.; SEDYMA, G. C.; VILLA NOVA, N. A. Evapotranspiração. 1. ed. Campinas, SP: FUNDAG, 2013. 323p.

PEREIRA, A. R. et al. Problemas operacionais com lisímetro de pesagem durante a estação chuvosa e em dias secos com rajadas de vento. Agrometeorologia, 10: 51-56, 2002 .

PRUITT, W. O.; ANGUS, D. E. Large weighing lysimeter for measuring evapotranspiration. Transactions of the American Society of Agricultural Engineers, 3: 13-18, 1960.

REICHARDT, K.; TIMM, L. C. Solo, planta e atmosfera: conceitos, processos e aplicações. 2. ed. Barueri: Manole, 2012. 500 p.

ROSENBERG, N. J. Evaporation and condensation on bare soil under irrigation in the East Central Great Plains. Agronomy Journal, 61: 557-561, 1969.

SANTOS, H. G. et al. Sistema brasileiro de classificação de solos. 5. ed. rev. e ampl. Brasília DF: Embrapa, 2018. 353 p

SANTOS, D. P. et al. Construção, instalação, calibração, performance e análise de funcionamento de lisímetros de pesagem cultivados com cana-deaçúcar. Agricultura Irrigada, 11: 1606 - 1616, 2017. 
SANTIAGO, A. V. Evapotranspiração de referencia medida por lisímetro de pesagem e estimada por Penman-Monteith (FAO-56), nas escalas mensal e decendial. 2001. 51 f. Dissertação (Mestrado em Agronomia: Área de Concentração em Física do Ambiente Agrícola) - Escola Superior de Agricultura "Luiz de Queiroz" - Universidade de São Paulo, Piracicaba, 2001.

SCHMIDT, C. D. S. et al. Design, installation and calibration of a weighing lysimeter for crop evapotranspiration studies. Water Resources and Irrigation Management, 2: 77-85, 2013.

SCHMIDT, C. D. S. Necessidade hídrica da cultura do fumo (Nicotianatabacum L.) tipo Sumatra cultivado em ambiente protegido do Recôncavo da Bahia - BA. 2008. 70 f. Dissertação (Mestrado em Ciências Agrárias: Área de Concentração em Engenharia e Manejo de Irrigação) - Universidade Federal do Recôncavo da Bahia, Cruz das Almas, 2008.

SILVA, G. S. et al. Análise de erros na determinação direta da evapotranspiração do cacaueiro jovem atribuídos ao sistema de medição. In: VII ON-LINE CONFERENCE - AGRONOMY, 2019, On-line. Anais... VII On-line Conference - Agronomy, 2019, 1: $1-8$.

SOIL SURVEY STAFF. Keys to Soil Taxonomy. 12. ed. Washington, DC: USDA - Natural Resources Conservation Service, 2014. 372 p.

VAN BAVEL, C. H. M.; MYERS, L. E. An automatic weighing lysimeter. Agricultural Engineering, 43: 580-588, 1962.

VELLAME, L. M. et al. Lisímetro de pesagem e de lençol freático de nível constante para uso em ambiente protegido. Caatinga, 25: 153-159, 2012.

VILELA, M. S. et al. Acurácia de um mini-lisímetro de pesagem eletrônica de baixo custo. Irriga, 1: 158$167,2015$.

WILLMOTT, C. J. On the validation of models. Physical Geography, 2: 184-194, 1981. 